\title{
A PLATERÍA EN LA BASÍLICA DE ALGEMESÍ (ss. XVI-XX)
}

FRANCISCO DE PAULA COTS MORATÓ

Departament d'Història de l'Art. Universitat de València Francisco.Cots@uv.es

\begin{abstract}
Resumen: Este artículo estudia la colección de plata de la Basílica de Algemesí (La Ribera Alta), formada por piezas cuya cronología abarca desde el siglo XVI al XX. Se indican las dataciones de las obras y sus marcas, asignándolas al obrador correspondiente. Las más importantes fueron labradas en los siglos XVI y XVIII, aunque también se realizan obras de platería en otras centurias.
\end{abstract}

Palabras clave: Algemesí / platería / marcas / ajuar litúrgico / Arte Valenciano.

\section{THE SILVERWARE AT THE BASILICA OF ALGEMESÍ (16TH TO 20TH CENTURY)}

Abstract: The silverware collection of the Basilica of Algemesí (La Ribera), formed by works dating from the 16 th to the 20th century, was studied. The different items (of the collection) were dated and their marks were assigned to the respective workshops. The most important pieces were produced in the 16th century and the 18 th century, although additional silverware was also commissioned in other centuries.

Key words: Algemesí / silverware / marks / liturgical objects / Valencian Art.

La orfebrería valenciana va conociéndose poco a poco en nuestros días. Aunque todavía se echa de menos un corpus que la estudie en su conjunto, no faltan trabajos parciales sobre ella. Interesante es estudiar la platería litúrgica, pues es la más abundante y la que se encuentra, la mayoría de las veces, en los lugares para los que fue labrada. Es cierto que los episodios acaecidos entre $1932^{2}$ y $1939^{3}$ mermaron la cantidad de piezas y también los archivos. A pesar de esto, varias de las obras de plata pudieron ser recuperadas y devueltas a sus lugares de origen, aunque existen algunas, más de las que quisiéramos, que están en sitios diferentes. Mencionamos al respecto el cáliz napolitano del arzobispo Rocabertí, de la catedral de Valencia, hoy en el monasterio de Gratia Dei en Benaguasil (El Camp de Túria). Solo la constante labor de campo puede recoger testimonios de este arte despre-

\footnotetext{
* Fecha de recepción: 15 abril de 2019 / Fecha de aceptación: 22 de julio de 2019.

1 Este trabajo se inserta en el proyecto La Catedral Barroca. Iglesia, sociedad y cultura en la Valencia del siglo XVII, financiado por el Ministerio de Economía y Competitividad. (HAR2016-74907-R). El autor agradece la ayuda del Rdo. S. Jesús Corbí Vidagañ y de Vicente Valls Soler, anterior párroco y sacristán de Algemesí respectivamente, por las facilidades otorgadas para estudiar la colección de platería e informar sobre algunas noticas referentes a la basílica. También al Rvdo. Joan Carles Alemany Vicens, párroco actual, Alejandro Cardona Ballester, Nuno Cruz Grancho, al Rvdo. Vicente Rovira Febrer, párroco de San Antonio Abad de Alginet (La Ribera Alta), al Rvdo. Eduardo Rengel Albert, párroco de Santa María de Cocentaina (El Comtat), José Vives Carrió y Víctor Iborra Romero. A este último le damos las gracias por acompañarnos a las iglesias y realizar todas las fotografías necesarias para el estudio y la publicación.

2 ANÓNIMO, "El asalto y quema de conventos en Valencia". Almanaque de Las Provincias. Valencia: Diario Las Provincias, 1932, pp. 257-272.

3 ANÓNIMO, "Valencia en 1936-1939". Almanaque de Las Provincias. Valencia: Diario Las Provincias, 1939, pp. 49-193.
} 
ciado, a pesar de ser de oro y plata, y escribir su brillante pasado en nuestras tierras. El presente artículo está en esta línea, pues estudia la colección de la Basílica de Algemesí (La Ribera Alta) con piezas que datamos desde el último tercio del siglo XVI hasta los años finales del siglo XX.

\section{La villa y la iglesia}

Algemesí es nombre que deriva del árabe y desde la conquista sabemos que el lugar fue repoblado por cristianos viejos. En un principio dependía de la jurisdicción de Alzira (La Ribera Alta), pero Felipe II le concedió el título de Universidad en 1574 y Felipe III el de villa real en 1608. Tenía voto en Cortes. ${ }^{4}$ La ciudad tiene cinco parroquias, pero la principal, y más antigua, está dedicada a San Jaime Apóstol. Ostenta el título de basílica menor desde 1986. La iglesia primitiva, excavada recientemente, ocupaba parte de la actual capilla de la Comunión. Esta última se comunica con la nave de la iglesia por tres grandes arcos y está presidida por la imagen de la patrona de la ciudad, la Virgen de la Salud. Es talla moderna, de madera policromada y encarnada, labrada por el escultor Felipe Panach Ballester en 1943. ${ }^{5}$ Reemplaza otra del siglo XV, que Sanchis Sivera no pudo estudiar por estar revestida de ropajes postizos. ${ }^{6}$ Es bien conocida, sin los atuendos añadidos, por fotografías y fue quemada en 1936.

El templo, situado en la plaza mayor de la ciudad, frente al ayuntamiento, se construyó en la segunda mitad del quinientos, junto con su fachada (1550-1582). La portada sigue el modelo de arco triunfal e incorpora imágenes de santos valencianos -Vicente Ferrer y Vicente Mártir- así como devociones locales -Jaime, Onofre y la Virgen de la Salud-. La torre campanario, dispuesta sobre el arco de la puerta principal en un alarde de virtuosismo técnico, es de 1703. Pascual Madoz, que escribe en la primera mitad del siglo XIX, indica: "Sensible es que por el incendio del archivo, ocurrido hace mas de 70 años, se ignore quienes fue- ron los inteligentes artífices autores de ambas obras [iglesia y torre], si por ventura fueron dos y no uno solo como el todo de la fachada da lugar à pensar". 7

Miguel Belda Ferré hace saber que el autor del plano y la obra de la iglesia es Domingo Gamieta. En 1575 se levantó acta ante el notario Paulo Tapia donde lee que

los honorables en mestre Juan de Alacant, pedrepiquer y mestre Juan Matali, pedrepiquer, experts nomenats per part dels obrers y proms de la obra de la Iglesia, se encarreguen de inspecsionar la obra, obliganse á manifestar si se ejecuta conforme á lo estipulat entre els obrers y Domingo Gamieta, mestre de esta obra. ${ }^{8}$

Antonio Ponz vio la iglesia en 1774, antes de su reforma neoclásica, y no le ahorra elogios:

Aunque yo no hice alto en la villa de Algemesí, sin embargo, me paré un poco en su iglesia parroquial, observando de paso la fachada que tenía, la cual puede llamarse buena entre las de toda esta tierra. ${ }^{9}$

El templo constaba de una nave con capillas y bóveda de crucería. Se restauró en 1896

y dos años después, el párroco, que lo era el Dr. D. José R. Ferri, hombre tan inteligente como emprendedor, acometió la atrevida empresa de hacerla claustral, siendo ésta la mejora más importante que se ha realizado en nuestro templo parroquial. ${ }^{10}$

De esta manera, con pasos abiertos entre las capiIlas, ha llegado hasta nosotros.

La basílica conserva numerosas pinturas entre las que sobresalen algunas del altar mayor de la mano de Francisco Ribalta (1565-1628), como señala Ponz. ${ }^{11}$ Los retablos laterales y sus imágenes, a excepción del Ilamado "de Pardines", de fines del siglo XVI o principios del XVII, son posteriores a la Guerra Civil, por destrucción de los primitivos. La iglesia también perdió parte de su patrimonio mueble en esos años.

\footnotetext{
${ }^{4}$ SANCHIS SIVERA, José. Nomenclátor Geográfico-Eclesiástico de los pueblos de la Diócesis de Valencia. Valencia: Tipografía moderna a cargo de Miguel Gimeno, 1922 (ed. facsímil, Valencia: París-Valencia, 1980), p. 60.

${ }^{5}$ FERRI CHULIO, Andrés de Sales. La Mare de Déu de la Salut d'Algemesí, Sueca: Basílica-Parroquia de Sant Jaume, 2004, p. 181.

6 SANCHIS SIVERA, José, $1922\left(n^{\circ} .4\right)$, p. 61.

7 MADOZ, Pascual. Diccionario Geográfico-estadístico-histórico de Alicante, Castellón y Valencia. Valencia: Institució Alfons el Magnànim, $2^{\text {a }}$ edición, 1987, Tomo I, p. 53.

8 BELDA Y FERRÉ, Miguel. Algemesí y su Patrona. Gandía: Imprenta de San Francisco de Borja, 1908, p. 135.

9 PONZ, Antonio. Viaje de España. Madrid: Aguilar, 1947, p. 398.

${ }^{10}$ BELDA Y FERRÉ, Miguel, 1908 (n 8), p. 134.

11 PONZ, Antonio, 1947 ( $n^{\circ}$ 9), p. 399. Véase también BENITO DOMÉNECH, Fernando. Los Ribalta y la pintura valenciana de su tiempo. Madrid: Diputación Provincial de Valencia, 1987 (Catálogo de Exposición).
} 


\section{La colección de platería}

No son muy numerosas las piezas artísticas de orfebrería de la basílica. La más antigua es el Relicario del Lignum Crucis, del último tercio del siglo XVI y las más recientes son varios cálices del siglo XX. Para su análisis, seguiremos un criterio cronológico y, dentro de este, uno tipológico. Expondremos sus características principales, obradores, marcas y medidas -estas en nota, para no interrumpir el discurso, siempre precediendo la altura a la anchura- relacionándolas con otras, valencianas o no, cuando lo consideremos conveniente. No estudiaremos algunos cálices del siglo XX, que no presentan demasiado valor artístico, aunque sí lo tienen litúrgico y sentimental, especialmente uno con el que celebró la Eucaristía en Roma Juan Pablo II en 1988. Casi todos están guardados en la vitrina del Trasagrario.

No hemos hallado hasta el momento noticias documentales referentes a las piezas de platería de la basílica, pues ya indicamos que el Archivo parroquial, excepto los Quinque Libri, desapareció a finales del siglo XVIII. Sí hay, en cambio, algunas reseñas bibliográficas que se refieren a ellas. Benito Ballester Broseta indica que

Los ornamentos y alhajas destinados al culto, son de valor y lujo, especialmente el hermoso viril y un terno y frontal, todo de alama de plata, bordados de oro fino...12

Este autor termina su Historia en 1874, pero Madoz, que publica antes su Diccionario (1845-1850), reproduce una de las frases de Ballester, aunque no completa, sin aportar más datos. ${ }^{13}$ Desconocemos quién se la facilitó, porque el político pamplonés tuvo muchos colaboradores a lo largo y ancho de España. Cercanas a nuestros días, cabe señalar unas cuantas publicaciones más. Eduard Sarrió Gonzalvo escribe un opúsculo en 1979, donde facilita numerosos datos sobre todas las obras que conservaba la entonces iglesia parroquial. ${ }^{14}$ Andrés de Sales Ferri Chulio, en 1992, da a conocer su estudio sobre las piezas de platería de La Ri- bera, entre las que están algunas de Algemesí15 y, al final de la década, Enrique López Català redacta la ficha catalográfica del Guion de la Virgen de la Salud, que participó en la exposición de la Luz de Las Imágenes, celebrada en la catedral de Valencia en 1999. ${ }^{16}$

El Relicario del Lignum Crucis, ${ }^{17}$ datado en dos de esos estudios como de los siglos XV y XVI respectivamente, es la pieza más antigua de la colección (Fig. 1). Es sumamente rico, de plata dorada, y ha sido labrado mediante la fundición, el cincelado y el repujado. Es un relicario procesional, con dos arandelas de fundición en la base, una a cada lado. La cruz se separa del astil, lo que permite incorporar un viril y servir como custodia como sucede en tantas otras obras valencianas. El pie es estrellado, con ocho lados y sin marcas. Presenta, con buen cincelado, figuraciones de animales fantásticos alados, peces y cabezas de angelitos también alados. En el anverso y en el reverso llama la atención una cabeza de niño encima de una cartela de cueros recortados (Fig. 1). Sobre la peana hay un cuerpo cuadrado en rombo, que con posterioridad derivará en el omnipresente cuadrado de inicio del astil de las custodias valencianas de los siglos XVII y XVIII. Tiene un nudo de jarrón adornado por guirnaldas figurando telas y flores, y cabezas aladas de angelitos. Este se acopla al rombo con tornapuntas. Encima del nudo hay dos arandelas unidas con "ces" de fundición y, sobre él, un cuello, muy estilizado, ornamentado con gallones de fundición, mascarones y acantos. Sigue un cuerpo redondo rematado por una crestería, donde se engarza la cruz latina con crucero cuadrado. En la parte delantera ostenta la reliquia de la Vera Cruz así como un Crucificado muerto con tres clavos. En la trasera un cuadrado con una cruz griega y flores. Los netos de los brazos presentan decoraciones vegetales, de líneas sinuosas, igual que las cruces mayores que comparten su misma cronología. Los remates son tiras entrelazadas y anudadas, modelo que también vemos en el Relicario del Lignum Crucis de Alginet (La Ribera Alta). Centran los extremos de los brazos ca-

\footnotetext{
12 BALLESTER BROSETA, Benet, Historia de la villa de Algemesí (ed. de V. J. Escartí). Algemesí: Ajuntament d'Algemesí, 2001, Vol. II, p. 55.

13 "Los ornamentos y alhajas destinadas al culto son de valor y lujo". Cfr. MADOZ, Pascual (nº 7), 1987, Tomo I, p. 53.

14 SARRIÓ GONZALVO, Eduard. Catálogo del museo de la iglesia parroquial de San Jaume Apóstol de Algemesí. Algemesí: Parroquia de Sant Jaume, 1979, s/p.

15 FERRI CHULIO, Andrés de Sales. La platería valentina -art religiós a La Ribera-. Sueca: Vicaría Episcopal de la Ribera, 1992, pp. 20, 25, 43, 52, 85, 108, 114, 120, 126, 133 у 135.

${ }^{16}$ LÓPEZ CATALÁ, Enrique. "Guion de la Virgen de la Salud", en BENITO DOMÉNECH, Fernando y SANCHO ANDREU, Jaime (com.). La Luz de las Imágenes, II. Áreas expositivas y análisis de obras. Valencia: Generalitat Valenciana, 1999, ficha $\mathrm{n}^{\circ} 223$, pp. 178-179 (Catálogo de Exposición).

17 Altura: 52.4, base: $26.2 \times 19$, cruz: $27 \times 23 \mathrm{~cm}$.
} 


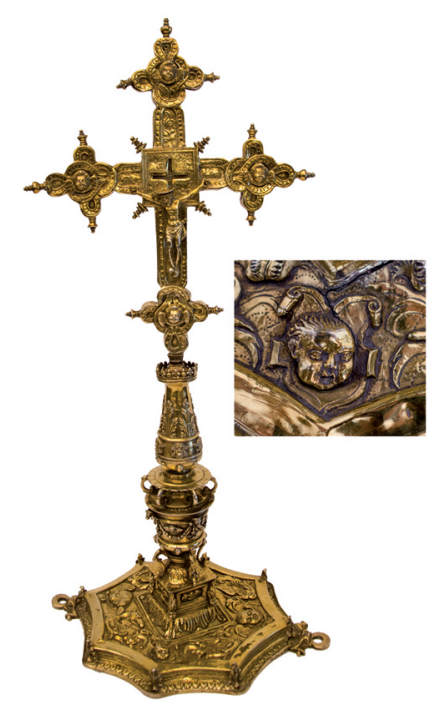

Fig. 1. Anónimo valenciano. Relicario del Lignum Crucis. Ca. 1575. Foto. V. Iborra.

bezas aladas de angelitos y los rematan perillones. La estructura abalaustrada y la decoración antes citada remiten la pieza a mediados del siglo XVI, pero las cabecitas sobre las dos cartelas de cueros recortados lo sitúan en el último tercio de la centuria. Pensamos que su datación más posible es ca. 1575, momento que coincide con la construcción de la fábrica de la iglesia. Muy posiblemente, a tenor de sus formas y ornamentación, es pieza salida de un obrador valenciano, aunque no hemos advertido en él ninguna marca. Muy similar a este es el que conservaba el Tesoro de la Virgen del Puig antes de 1936. Este último es conocido por fotografía. ${ }^{18}$ También es muy semejante al Lignum Crucis de la parroquia de San Antonio Abad de Canals (La Costera) y a la cruz del Relicario del Lignum Crucis de la iglesia de San Martín de Valencia, cruces todas datadas en la segunda mitad del siglo XVI.

El Lignum Crucis ${ }^{19}$ de la parroquia de San Antonio Abad de Alginet (La Ribera Alta), ca. 1590, que hemos comparado con este de Algemesí, debe pertenecer al mismo obrador (Fig. 2). La cruz, con los remates de los brazos anudados, es muy semejante. Está marcado con la de Valencia y labrado

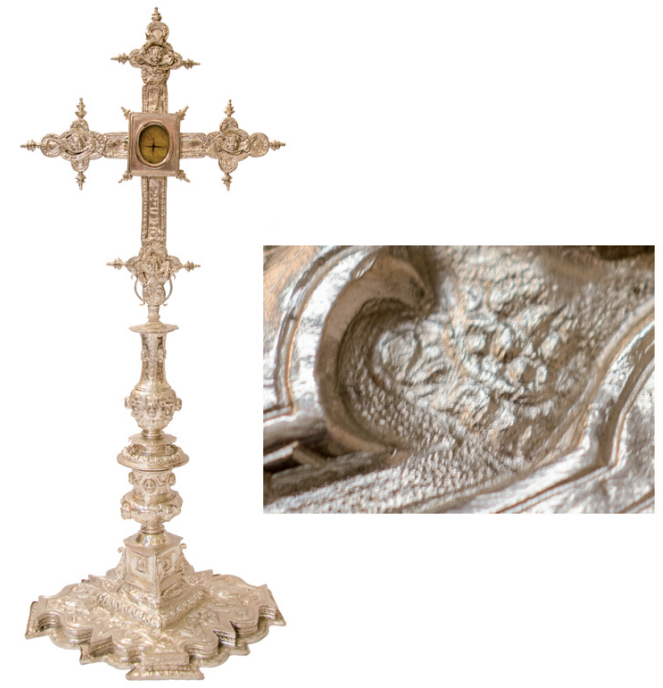

Fig. 2. Anónimo valenciano. Relicario del Lignum Crucis. Ca. 1590. Iglesia parroquial de San Antonio Abad. Alginet. Foto V. Iborra.

en plata blanca. No incorpora el Crucificado y tiene un cuadrado con un óvalo donde falta la reliquia. Tampoco tiene las arandelas que lo convertirían en procesional. Presenta motivos de cueros recortados en la base, por todo el astil y un nudo de fines del XVI sin guirnaldas ni mascarones. Pensamos que es un tanto posterior al anteriormente estudiado, porque adopta unos motivos decorativos que solo están esbozados en el de la basílica de San Jaime. Ambas piezas son obras de alta calidad y realizadas por un artífice que siente deseos de novedad y que conoce muy bien los motivos ornamentales del último tercio del quinientos.

Procedente del convento de dominicos de la ciudad, llega un relicario de san Vicente Ferrer ${ }^{20}$ a la parroquia en 1836. Es una pieza de ca. 1680, de cobre dorado, con base redonda y nudo ovoide. Se adorna por costillas y tiene una cruz prismática, extraña para el momento de su factura. La segunda parte de la pieza, donde figura la reliquia dentro de un óvalo, tiene forma de templete $y$ presenta cuatro pequeñas columnas abalaustradas rematadas por bolas. Es obra modesta y de factura simple.

18 Está reproducido en SARTHOU CARRERES, Carlos, en colaboración con MARTINEZ ALOY, José. Provincia de Valencia, en CARRERAS CANDÍ, Francisco. Geografía General del Reino de Valencia. Tomo II. Barcelona: Establecimiento Editorial de Alberto Martín [s/f], p. 771

${ }^{19}$ Altura: 55, base: $23.5 \times 20$, cruz: $25.8 \times 23 \mathrm{~cm}$.

${ }^{20}$ Altura: 33 , base: $10.8 \mathrm{~cm}$. 
Sarrió indica que la imagen del retablo "de Pardines" tiene una "corona, nimbo y azucena, orfebrería en plata de la época", ${ }^{21}$ es decir, del momento de su imagen titular, principios del siglo XVII. Reproduce una fotografía donde están presentes las tres. Esta idea nos parece plenamente acertada. La corona ${ }^{22}$ y la diadema, ${ }^{23}$ ambas de plata blanca, están batidas, cinceladas y repujadas. Fijamos su datación ca. 1620. La corona muestra una crestería con cueros recortados, óvalos, "ces", cabezas aladas de angelitos y cestos de flores (Fig. 3). Toda esta decoración nos remite a principios del siglo XVII. La pieza precisa restauración, pues parte de la crestería y la base están rotas. Una inscripción en la cinta, en capitales romanas, refiere la concepción inmaculada de María: "TOT[A] PVLCRA AMICA MEA ET MACVLA NO", parte del célebre versículo del Cantar de los Cantares $(4,7)$ y que da nombre a un tipo de representación icónica de la Purísima. El conjunto se completaba con unas azucenas que la imagen de la Virgen llevaba en una mano. De momento estas flores de plata no las hemos hallado en la basílica. ${ }^{24}$

La diadema (Fig. 4) tiene rayos de sección romboidal, lisos y flameados, con la estrella canónica de María -la de ocho puntas-. En la parte baja presenta tres pequeños rayos a cada lado, que la relacionan directamente con la diadema de la Virgen con el Niño de la catedral de Segorbe (Alt Palancia), obra del célebre Eloi Camanyes (1546?1630), de 1618. El reposacabezas de Algemesí tiene, además, una decoración cincelada de flores, pequeñas perlas y tiras de ondas. Presenta un regular estado de conservación y advertimos el testigo de alguna restauración de hace bastante tiempo: hay un rayo y estrella añadidos después a la factura original de la diadema.

También se conserva una coronita imperial, ${ }^{25}$ ca. 1790 , de plata blanca, cincelada y repujada, con el orbe de cobre plateado, este posterior a la hechura de la pieza. Le falta un imperial y muestra óvalos con un cristal tallado -dos verde esmeralda y uno amarillo- en el centro de tres de ellos. La de- coración es la habitual de fines del setecientos y comienzos del ochocientos: acantos, flores, óvalos, tondos así como las habituales "redes" rococó. No hemos visto marcas en ella. Es una obra correcta, pero presenta un penoso estado de conservación. Desconocemos a qué imagen pertenece.

Ferri Chulio informa ${ }^{26}$ que el platero valenciano José Bonacho David ${ }^{27}$ labra la Corona Rica de la Virgen de la Salud en 1950, pues María es reina como no deja de proclamar el arte de los siglos XII y XIII. Es una suntuosa pieza (Fig. 5), con doble fila, una encima de otra, de ocho imperiales rematados por el orbe y la cruz. Está realizada en oro amarillo y con numerosas joyas, donadas por la piedad popular, engastadas sin desmontar ni fundir. ${ }^{28}$ Son, sobre todo, pendientes y sortijas, de oro y platino con diamantes rosas, de aderezos de mujer de finales del siglo XIX y de la primera mitad del siglo XX, así como dos pequeños hilos de perlitas en el orbe. También tiene numerosas joyas engastadas en su interior. La complementan cuantiosos medios cuerpos y cabecitas de ángeles alados tallados en marfil así como esmaltes. Posee cuatro de estos que representan la aparición de la imagen en la morera, la coronación canónica por el arzobispo Prudencio Melo, la beata Josefa Naval Girbés instruyendo a algunas de sus discípulas y el escudo de la ciudad de Algemesí. Es obra de gran empeño económico, realizada en tiempos de mucha dificultad. En 1982, después del desastre del pantano de Tous (La Ribera Alta), fue intensamente restaurada por Agustí y Amaya, orfebres locales, especialistas en aderezos de labradora, que la desmontaron, limpiaron y adhirieron nuevas joyas supliendo las perdidas por el agua. Se utiliza en las fiestas del 7 y 8 de septiembre y alguna que otra solemnidad, como la del último domingo de abril. Durante el año, la imagen de la Virgen luce otra corona, muy similar, de cobre dorado.

Pertenecientes también a esta imagen, la basílica guarda dos diademas. La más antigua, ${ }^{29}$ y de mejor calidad, fue labrada por Francisco de Paula Pa-

\footnotetext{
21 SARRIÓ GONZALVO, Eduard, 1979 ( $\left.n^{\circ} 14\right), s / p$.

22 Altura: 8.2 , base: $7.5 \mathrm{~cm}$.

23 Altura: 22.5, anchura: $23.7 \mathrm{~cm}$.

${ }^{24}$ El rector S. Jesús Corbí Vidagañ, que tomó posesión de la basílica en 2006 y estuvo a su cargo hasta 2019, nos indica que él no conoció nunca las azucenas en las manos de la imagen de la Virgen.

25 Altura: 12.5 , base: $6.7 \mathrm{~cm}$.

26 FERRI CHULIO, Andrés de Sales, 2004 ( $\left.n^{\circ} 5\right)$, pp. 224-225.

27 Era sobrino, hijo de un primo hermano, del también platero José David Esteve (1883-1966). Su obrador fue continuado por José Bonacho, hijo.

28 Altura: 33.5 , base: $12 \mathrm{~cm}$.

29 Diámetro: $55 \mathrm{~cm}$.
} 


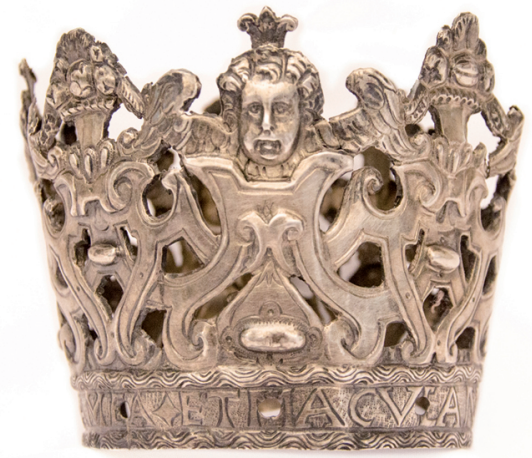

Fig. 3. Anónimo valenciano. Corona. Ca. 1620. Foto V. Iborra.

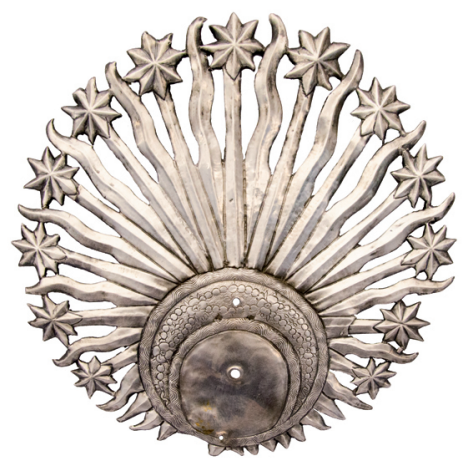

Fig. 4. Anónimo valenciano. Diadema. Ca. 1620. Foto V. Iborra.

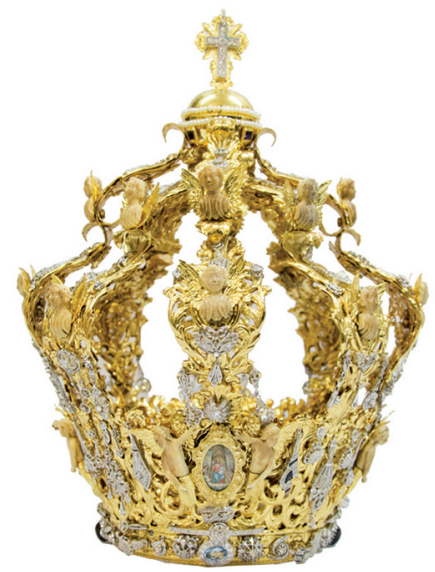

Fig. 5. José Bonacho David. Corona Rica de la Virgen de la Salud. 1950. Foto V. Iborra. jarón ${ }^{30}$ Suay (1888-1980). ${ }^{31}$ Es de plata dorada y reproduce la de la Coronación canónica de 1925, diseñada y labrada por el platero José Vilaplana, con algunas variantes. Está realizada por medio del cincelado, fundición y repujado, y se adorna con topacios y piedras blancas talladas. Es un aro con cabezas de ángeles alados y haces de rayos de diferente longitud, de influencia barroca y rococó, con una crestería de flores de lis, rematada por estrellas de ocho puntas. Muestra, a los lados, dos de las Excelencias de María: el pozo (Cant 4, 15) y la fuente (Cant 4, 12), y ostenta el Anagrama de María en la parte superior. Una inscripción informa de su donante así como del año de la factura: "A EXPENSAS DE DON AMPARO / NICLÓS ESTEVE EN PIADOSA / MEMORIA DE LOS RVDOS / HERMANOS D. JUAN Y D. RAMÓN / NICLÓS ESTEVE / ALGEMESí 8-9-1943". Se utiliza junto con la Corona Rica para las fiestas de la Virgen. La otra diadema, ${ }^{32}$ como sucede con la segunda corona anteriormente mencionada, es de cobre dorado. Los motivos decorativos y las Excelencias son las mismas y la porta la imagen durante el año.

La custodia procesional ${ }^{33}$ más antigua es de ca. 1680, como demuestran sus formas y ornamentación (Fig. 6). Esta labrada en cobre y bronce dorados y tiene cuatro arandelas de bronce fundido en la base. El viril, de bronce dorado, es posterior a 1936. Realizada mediante el batido, fundición, repujado y picado de lustre, puede dividirse por la mitad para dar, con la parte superior, la bendición con el Santísimo Sacramento. Sobre la base redonda, decorada con esmaltes azules sobre cartelas de plata blanca y óvalos repujados, está el cuerpo cuadrado -prueba de su valencianía-, en rombo, al inicio del astil. Encima de él, encontramos el cilindro entre dos platos con asas. El nudo es de jarrón, también con asas. Forma la segunda parte del astil un cuello que exhibe acantos y cabezas aladas de querubines. El sol tiene rayos de sección romboidal donde alternan los lisos y los flameados. Van rematados por estrellas de once puntas que tienen un cristal blanco tallado en el centro. Lo corona una cruz latina plana con bolas en los extremos. Sarrió la atribuye a Prudencio Marín y la data en el siglo XVI. ${ }^{34}$ Sobre esto diremos que,

30 FERRI CHULIO, Andrés de Sales, 2004 ( $\left.n^{\circ} 5\right)$, p. 176.

31 Francisco de Paula Pajarón Suay fundó el obrador que fue continuado por su hijo Francisco de Paula Pajarón Andreu (19241998). Hoy lo regentan sus nietos. Agradecemos a Loreto Pajarón Gamón, que nos facilitara esta información, así como las cronologías, y que buscara referencias de la diadema, que lamentablemente no encontró, en el Archivo familiar.

32 Diámetro: $55 \mathrm{~cm}$

33 Altura: 92, base: 39.8 , diámetro del sol: $39 \mathrm{~cm}$

34 SARRIÓ GONZALVO, Eduard ( $\left.n^{\circ} 14\right), 1979, \mathrm{~s} / \mathrm{p}$. 
desde el estudio de José María Pérez, ${ }^{35}$ se asigna al castellano Prudencio Marín (1634?-1704), examinado en Valencia en 1660, la custodia de Xèrica (Alt Palancia), que seguramente le pertenece. El problema es que Pérez leyó en los archivos el año de factura de esta pieza como 1584, cuando Marín todavía no había nacido. Pensamos que la fecha correcta debe de ser 1684. Las formas de la custodia de Xèrica son de la segunda mitad del siglo XVII, no del XVI. Cabe decir que, en el siglo XVII, los modelos se repiten con frecuencia por diferentes maestros y esta custodia está en esa línea. Por ello, debido a la ausencia de inscripciones, no podemos asignarla a un orfebre, pero remarcamos que sí es una obra valenciana.

La basílica guarda tres custodias más. La más pequeña (Fig. 7) tiene un pie, astil y nudo de cobre y bronce dorados y es de ca. 1680. La parte superior, con los ángeles, brazos y viril, es de cobre y bronce dorados, de ca. 1985, y la realizó el obrador de José Bonacho, hijo. ${ }^{36}$ En esta última fecha también añadieron a la peana cuatro cabecitas de ángeles alados de plata blanca y dos campanitas del mismo material en los brazos del árbol. Las técnicas con las que labraron las partes del XVII son el batido, fundición y picado de lustre. En la peana, a cincel, el artífice representa cuatro pavos reales. Uno de ellos tiene la cola abierta, mientras que los otros tres no. No hay uno igual a otro. El pavo es un animal solar y se identifica con Jesús, ${ }^{37}$ Dios solar en sí mismo y príncipe de la resurrección. Este animal es símbolo de la inmortalidad e incorruptibilidad. Es adecuado que esté en las custodias, donde se expone, según venera la Iglesia católica, el pan transmutado del resucitado, el cuerpo del mismo Cristo y también viático para la difícil travesía del desierto que es la vida, muchas veces llena de penalidades. La parte superior del astil se abre "en árbol" como en tantas custodias del siglo XVII y sostiene a dos angelitos danzantes. El sol es circular con una serie de rayos cortos, donde alternan los lisos y los flameados. Se remata por una cruz abalaustrada, típica del siglo XVIII. ${ }^{38}$

Las otras dos custodias son de la segunda mitad del siglo XX. La primera, ${ }^{39}$ ca. 1945, es obra del pla-

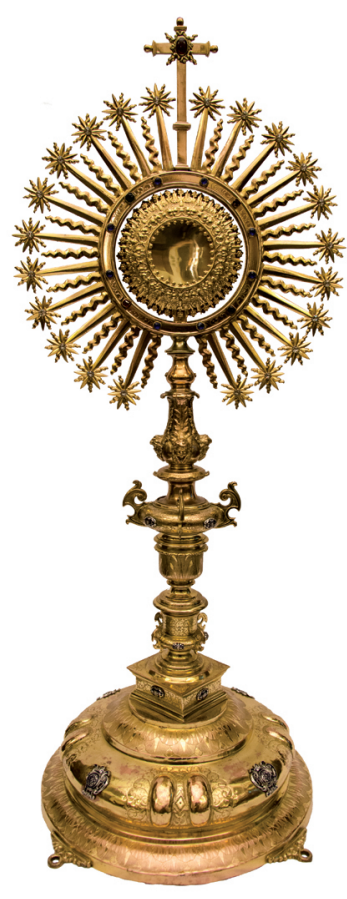

Fig. 6. Anónimo valenciano. Custodia procesional. Ca. 1680. Foto V. Iborra.

tero valenciano José David Esteve (1883-1966). Está labrada en plata blanca, cobre y bronce dorados, y se adorna con cristales de colores y perlas de aljófar. Es una pieza que puede desmontarse en dos para dar la bendición con el Santísimo Sacramento. Las formas mezclan, en dudosa armonía, como sucede en muchas piezas valencianas de la segunda mitad del XX, rasgos góticos y rococó. Descansa sobre una doble basa abombada con pequeños pies con cartelas que incorporan una cabeza de ángel alado. En la primera, de cobre dorado, hay decoraciones lanceoladas y tres relieves de plata blanca con el Arca de la Alianza, el Ave Fénix y el Cordero sobre el Libro de los Siete Sellos. Sobre el segundo cuerpo, también en plata blanca, las imágenes de bulto de Cristo como Buen Pastor, la Purísima Concepción, san José con

35 PÉREZ, José María, "Orfebres o argenteros en la Arciprestal de Jérica". Anales del Centro de Cultura Valenciana, 1935, n²3, 13-23.

36 Altura: 54.5 , base: 23.3 y diámetro del sol: $18 \mathrm{~cm}$.

37 Esta idea aparece en libros antiguos como El Fisiólogo, Cfr. SEBASTIÁN, S. El Fisiólogo. Atribuido a san Epifanio, seguido de El Bestiario Toscano. Madrid: Tuero, 1986, pp. 75-79. Véase también CHEVALIER, Jean y GHEERBRANT, Alain. Diccionario de los Símbolos. Barcelona: Herder, 1986, pp. 807-808.

38 Eduard Sarrió Gonzalvo tenía el pie y mandó hacer la parte superior con el sol.

39 Altura: 88 , base: 37 , diámetro del sol: $50 \mathrm{~cm}$. 


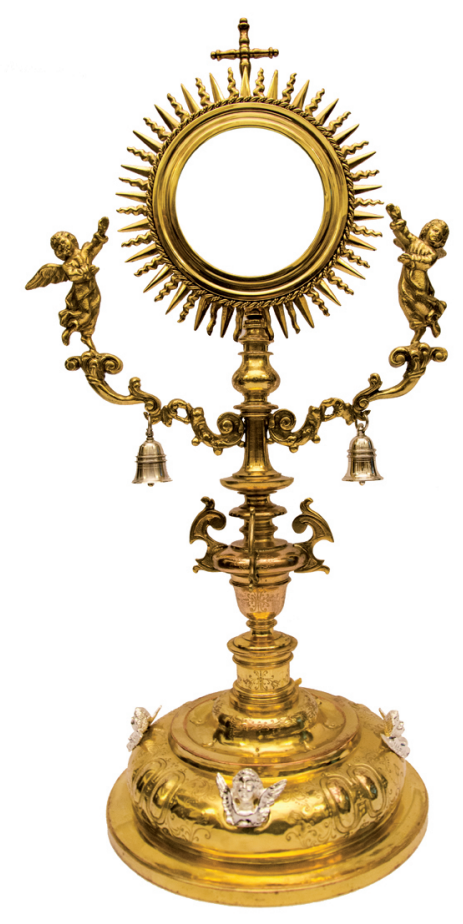

Fig. 7. Anónimo y José Bonacho, hijo. Custodia. Ca. 1680 y $c a$. 1985. Foto V. Iborra.

el Niño y san Vicente Ferrer. El nudo es "gótico", redondo y achatado, al que sucede la segunda parte del astil, que es circular. Sobre este reposa el sol formado por cuatro flores de lis en forma de cruz, de lejana tradición gótica, con dos círculos concéntricos de donde parten los haces de rayos de diferente longitud, frecuentes en Valencia desde el Rococó. Lo remata la paloma del Espíritu Santo con las alas desplegadas y complementan el sol numerosas cabezas de ángeles alados.

La iconografía alude a Jesucristo y a la Eucaristía. El Arca de la Alianza refiere la Antigua Ley al mismo tiempo que el sagrario de la Nueva; el Ave Fénix figura la resurrección de Jesús y el Cordero sobre el Libro de los Siete Sellos alude al Apocalipsis. Cristo es el único que puede abrir los sellos porque ha sido degollado por toda persona, pueblo y nación (Ap. 5, 9). Continúan el mensaje las imágenes de los tres miembros de la Sagrada Familia con el santo y predicador valenciano más universal, tam- bién presente en la fachada de la basílica desde la segunda mitad del siglo XVI. En la parte superior del sol hay dos golpes de flores. Aluden a la primavera que Jesús trae sobre el mundo con su nacimiento, vida, Pasión y Resurrección. Es necesario decir que lo icónico en esta pieza no presenta un programa coherente, completo ni ordenando, rasgo muy característico de las custodias valencianas de la segunda mitad del siglo $X X$, sin que sepamos a qué se debe, si al mentor $o$ al artífice. Lo que es un hecho es que la cultura simbólica a nivel general ha decaído. Simplemente lo icónico en esta pieza incorpora imágenes diversas y sueltas con un punto en común: la figura del Hijo.

Sarrió indica que la Custodia Procesional del Corpus $\mathrm{Christi}^{40}$ es obra del orfebre valenciano Antonio David, de $1960 .{ }^{41}$ En realidad estos plateros responden al nombre de José, tanto el padre y fundador, José David Esteve (1883-1966), como el hijo y continuador, José David Marqués (19151991). ${ }^{42}$ José David Esteve instituyó su obrador en Valencia en 1929, taller que es regido por la tercera y cuarta generación de estos plateros. Es pieza labrada en plata blanca y dorada (Fig. 8). Está marcada en la base con J. David, la estrella de calidad de España y el 915 de la ley de la plata. También incorpora numerosas joyas engastadas sin desmontar, esmaltes y marfiles. Descansa sobre un alto pie lobulado "gótico", que se apoya en cuatro volutas perforadas, necesarias para asirla a las andas. Esta peana es dorada, abombada y muestra, repujados, espigas de trigo, pámpanos y racimos de vid. Sobre ella están cuatro imágenes de santos de plata blanca: Vicente Ferrer, Vicente Mártir, Juan el Bautista y Pascual Bailón. De entre estos parte un robusto astil con un nudo de templete que tiene cuatro columnitas de marfil. Este último se apoya sobre un cuerpo gallonado con cuatro asas "barrocas". En las caras del nudo, en el sentido de las agujas del reloj, están el Santo Cáliz con la Hostia, dos corderos flanqueando un cáliz, el Pelícano y el cesto de panes y peces con la Hostia. El interior de la custodia está constituido por armazones de hierro y madera.

La parte superior del nudo tiene un cuerpo inspirado en las macollas de algunas de las custodias de Bernardo Quinzà (1752-1803), como la de Cullera (La Ribera Baixa). Incorpora tres figuras de plata blanca que representan las virtudes teologa-

\footnotetext{
${ }^{40}$ Altura: 153 , base: 58.2 , diámetro del sol: $68 \mathrm{~cm}$.

41 SARRIÓ GONZALVO, Eduard, 1979 ( $\left.n^{\circ} 14\right) \mathrm{s} / \mathrm{p}$.

${ }^{42}$ Agradecemos al Obrador de Vicente David, Orfebrería Religiosa David, que nos facilitara las cronologías de su padre y abuelo.
} 
les: Fe, Esperanza y Caridad. Sobre ellas descansa el Cordero apocalíptico en el Libro de los Siete SeIlos. Estos están representados por siete pendientes, joyas de mujer, de oro y pedrería. El sol, como acontecía en la custodia anterior, muestra una cruz con remates "de lises", esta vez muy diluidas, adornadas de tornapuntas y "ces". Seguidamente corre una serie de rayos de diferente longitud, donde alternan los lisos y flameados -son un recuerdo a los rayos del siglo XVII, aunque algunos terminan en un pequeño motivo abierto, ya advertido en las "lises"-. Sobre los rayos hay espigas de trigo y racimos de vid de perlas, así como cabezas de ángeles alados de marfil. También encontramos cuatro esmaltes que figuran a san Jaime, titular de la basílica, san José con el Niño, esposo de María, la Virgen de la Salud, la patrona de la ciudad, y san Luis Gonzaga. La cruz superior, de buen tamaño, vuelve a inspirarse en las piezas "góticas" del siglo XIX.

Es evidente que el orfebre José David Esteve ha realizado una custodia de gran suntuosidad y de gran empeño económico. Es una custodia "sol", que mezcla motivos ornamentales del barroco del XVII, de las "custodias escultóricas" valencianas del XVIII y del "gótico ideal" del siglo XIX. Las joyas sin desmontar, donadas por la piedad popular y repartidas por el sol, y los ángeles de marfil exponen la gran influencia que sobre este ostensorio tiene la Corona Rica de la Virgen de la Salud (1950), obra, como ya se ha dicho, de otro platero valenciano, José Bonacho David, sobrino de José David Esteve.

Al igual que acontecía en el anterior viril, tampoco este tiene un programa iconográfico cerrado y con un sentido completo. Si la función de la iconografía, como de cualquier mensaje, en palabras o imágenes, es transmitir la Sabiduría, iluminar e instruir, advertimos poca coherencia en la de este ostensorio. En él se mezclan devociones locales y particulares junto con la Eucaristía. Los símbolos están repartidos por toda la pieza: los racimos y las hojas de parra -referentes a la sangre salvadora-; la cesta de los panes y las espigas de trigo -el pan transmutado-; la Eucaristía como el sacrificio incruento que rememora la Crucifixión cada día en el altar -el Santo Cáliz, el Pelícano y el Cordero

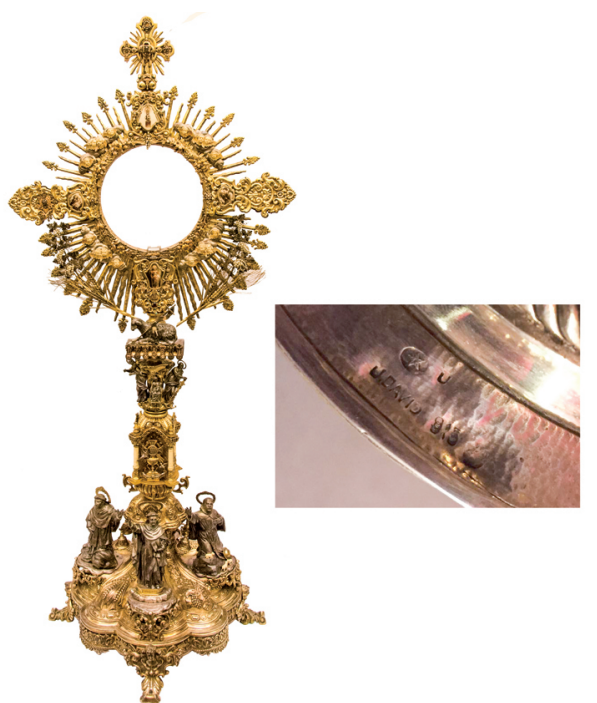

Fig. 8. José David Esteve. Custodia procesional del Corpus Christi. 1960. Foto V. Iborra.

de los Siete Sellos-; santos patronos y devociones particulares de los miembros de la familia que sufragó el viril43 - Vicente Mártir, Vicente Ferrer y Pascual Bailón, enamorado del "pan vivo celestial", como refieren sus Gozos-, así como la Virgen de la Salud, patrona de la ciudad, el apóstol Jaime, titular de la iglesia, san José y san Luis Gonzaga. Pero hay que recordar que toda devoción aquí figurada, toda piedad, todo arrebato místico, no tiene sentido sin las obras, el único bagaje que necesitamos en el momento supremo. La Fe sin obras no sirve para nada. Por eso están las Virtudes Teologales presentes al final del astil, virtudes que valdrán cuando "A la tarde te examinarán en el amor", ${ }^{44}$ sin las cuales no podremos superar la prueba.

Del techo de la capilla funeraria de la beata Josefa Naval Girbés pende una bella lámpara del siglo XVIII (Fig. 9), ${ }^{45}$ que presenta un magnífico estado de conservación, comprada en el mercado de antigüedades de Madrid en $1988 .{ }^{46}$ Está labrada en plata blanca por medio del cincelado, el moldeado, el recortado, el repujado y con las cadenas que la sustentan, y también las interiores dispues-

\footnotetext{
${ }^{43}$ Fue la familia del beato Pascual Ferrer, quien también abonó el retablo y las imágenes de la capilla de San Vicente Ferrer de la basílica.

${ }^{44}$ CRUZ, Juan de la, Obras Completas. Burgos: Editorial Monte Carmelo, $8^{a}$ edición, 2003, p. 100.

${ }^{45}$ Altura total: 120, anchura máxima: $62 \mathrm{~cm}$. Está a considerable altura y no puede bajarse, por lo tanto no hemos podido estudiarla en profundidad.

${ }^{46}$ Eduard Sarrió Gonzalvo la compró y la costeó doña Joaquina Marco.
} 


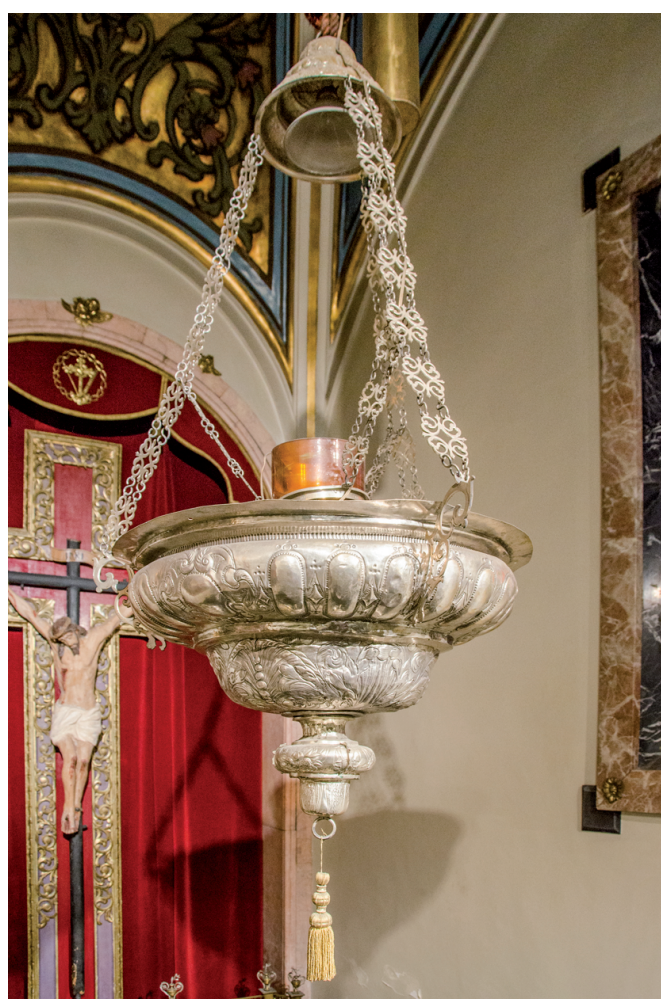

Fig. 9. Anónimo. Lámpara. Ca. 1720. Foto V. Iborra.
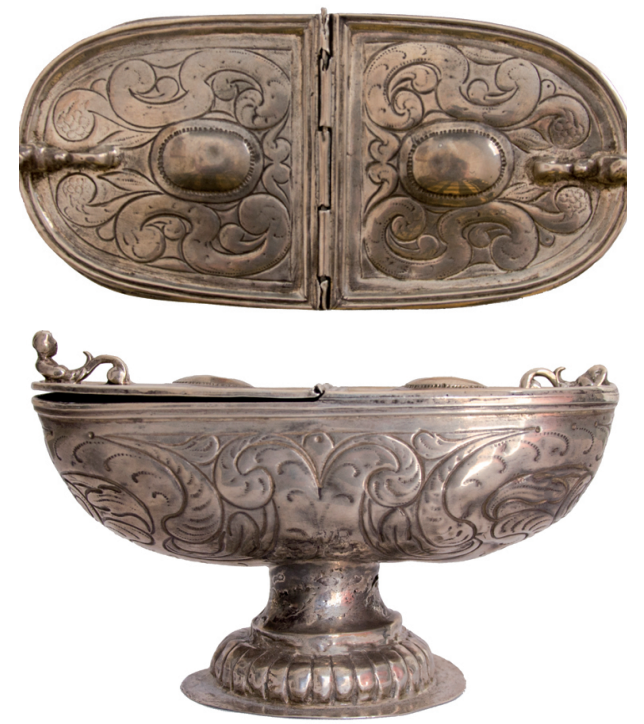

Fig. 10. Anónimo valenciano. Naveta. Ca. 1730. Foto V. Iborra. tas para mantener el vaso, de fundición. La estructura es propia del setecientos, más concretamente de su primera mitad. La bolla con borde saliente, el adorno vegetal, principalmente de relevados acantos, el remate periforme invertido, las cuatro tornapuntas -"ces"-, que reciben las cadenas, una cierta alternancia de cuerpos cóncavos y convexos, la decoración de toros, la ausencia de escocia y los óvalos rematados por punteado, permiten datarla ca. 1720. Difícil es saber, por el momento, el obrador donde se realizó, pues no hemos visto marcas.

De ca. 1730 es una naveta de plata blanca ${ }^{47}$ que no conserva la cucharilla original ni el incensario (Fig. 10). Tampoco está marcada. Labrada mediante el batido, cincelado, fundición y repujado, presenta motivos curvilíneos y vegetales, ligeramente relevados, gallones y óvalos rematados por punteado. Las dos figurillas, como si fueran sirenas, de la popa y la proa son de fundición. Los motivos ornamentales la encuadran en el Barroco pleno y forzosamente ha de datarse antes de 1733, cuando las ordenanzas de Colegio de Plateros de Valencia y Reino de ese año incorporan el triple marcaje castellano en Valencia y comienza de nuevo el marcaje con bastante regularidad. Muchas piezas valencianas de los últimos años del siglo XVII y del primer tercio del XVIII no están marcadas. Se marca a raíz de las nuevas ordenanzas de 1733. En ese año se abre un libro de marcas que conserva hoy en día solo cinco hojas volantes. ${ }^{48}$

El Guion de la Virgen de la Salud ${ }^{49}$ es pieza magnífica del Rococó valenciano (Fig. 11). Ha sido restaurado en varias ocasiones y, en la actualidad, se conserva en muy buen estado. Está labrado en plata blanca y cobre dorado en esa combinación tan suntuosa que los plateros utilizan a menudo. Es un gran marco de rocalla, con "ces" y "eses", realizado con varias planchas, cinceladas y repujadas, sobre una tabla forrada de terciopelo rojo. Incorpora un lienzo moderno de Francisco Calatayud Llobell, que figura la imagen mariana patronal. Alrededor están varias de las Excelencias, aunque algunas son nuevas, hechas según modelos originales: la estrella matutina (Ap 2, 28), la fuente sellada (Cant 4, 12), la palmera (Eclo 24, 18) y el pozo (Cant 4, 15), así como varias flores. Arriba se dispone el titular de la basílica, Jaime, en una actitud tan poco caritativa como es la de matar moros. El Guion presenta las marcas de Jo-

47 Altura: 8, base: 10.3 y longitud: $16.4 \mathrm{~cm}$.

48 COTS MORATÓ, Francisco, Estudio histórico-artístico del templo parroquial de Santa María la Mayor de Oliva. Oliva: Ajuntament d'Oliva, pp. 174-187, doc. IX.

49 Altura: 153.5 , anchura: $122 \mathrm{~cm}$. 
sep Bellmont (1713-1787) y de Pasqual Velasco (1697?-1774/75), autor y marcador respectivamente (Fig. 14). Josep Bellmont es platero de plata y discípulo del maestro de la catedral de Valencia Gaspar Lleó (1700-1742)..$^{50}$ Tiene obras destacadas como el bellísimo Cáliz del canónigo Carrillo (1783/84), de la Seo de Valencia. Velasco es platero de oro y mayoral primero del Colegio de Plateros entre el 26 de junio de 1757 y el 25 de junio de $1761 .^{51}$ En esos años hay que situar la factura y el marcaje del Guion.

Junto a esta espléndida pieza, el primer Juego de Sacras, ${ }^{52}$ con las mismas marcas, no le va a la zaga (Fig. 12). La cronología es la misma y las marcas también. Posiblemente se encargarían al mismo tiempo al obrador de Josep Bellmont. Las tres son de plata blanca y cobre dorado sobre alma de madera pintada de rojo. Así debió de lucir también el Guion en su origen. Nos lo confirman varias obras valencianas como las extraordinarias Sacras de la iglesia de la Asunción Llíria (El Camp del Túria), de 1768, obra de Marià Joan (1733-1786). Las de Algemesí siguen, como la mayoría de las valencianas, el modelo "de escudo" tan repetido en nuestras tierras. Hay otro juego de sacras, de metal plateado e inspiradas en el Rococó, datadas en la segunda mitad del XIX como muy pronto. No presentan en absoluto la calidad de las anteriores.

Del tercer cuarto del siglo XVIII es el "Tarchón" de la cama de la Virgen de Agosto. La función de esta pieza es mostrar y sostener las Excelencias de María a los pies del túmulo de la Dormición. A diferencia de la mayoría de las cartelas del país -Oliva (La Safor), Seo de Valencia o Sueca (La Ribera Baixa)-, esta no es de plata ni de metal, sino de madera plateada y dorada. Es una gran plancha de rocalla simétrica que incorpora numerosos espejos (Sab 7, 26), una de las Excelencias de la Señora, y flores, pero ninguna otra más. Desconocemos si las tuvo en el pasado, ya que es lo habitual en los ricos ajuares valencianos de plata de la Dormición, de la que es pieza privilegiada.

La Cruz procesional, ${ }^{53}$ posiblemente de la década de 1780 o quizás algo posterior, es una pieza muy destacada de la colección (Fig. 13). Está labrada en plata blanca y dorada, y en cobre dorado. Ha sufrido más de una restauración y algunos motivos

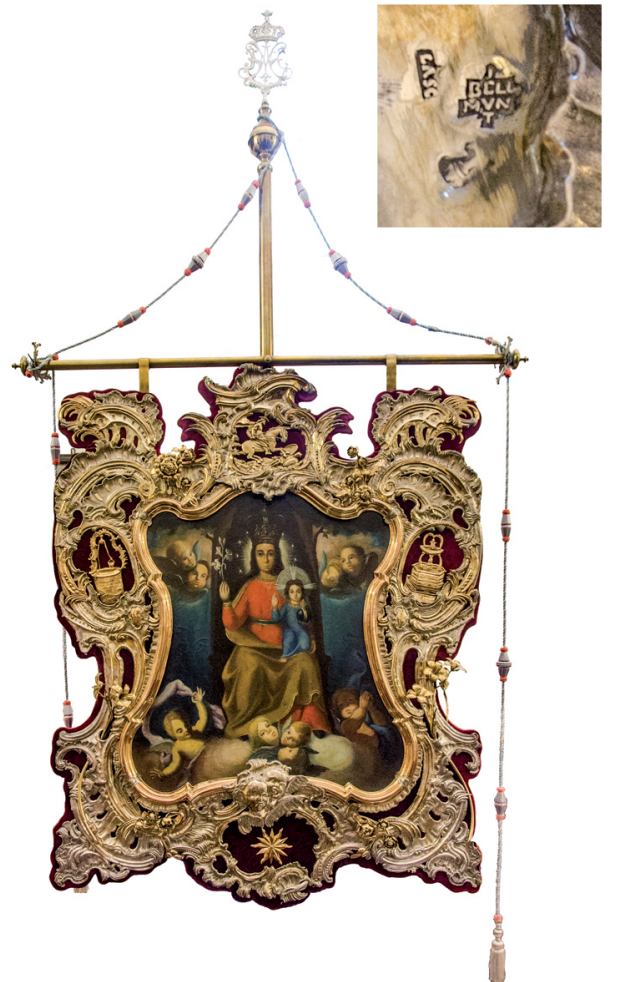

Fig. 11. Josep Bellmont. Guion de la Virgen de la Salud. 1757-1761. Foto V. Iborra.

dorados han sido sustituidos por copias siguiendo los originales. Está formada por diversas planchas de plata, cinceladas y repujadas, dispuestas sobre un alma de madera. Se separa del asta, también de madera, que va revestida de plata blanca. No presenta marcas. En el anverso muestra a Cristo muerto, con tres clavos, y coronado de espinas y ninguna otra imagen en el reverso. De brazos ondulantes, termina en pomos dorados ornamentados con tiras de ochos entrelazados. Exhibe un cosmos con ángeles como nudo. La rocalla está repartida por toda la pieza, especialmente en el asta, que también se adorna con flores. Es una rocaIla bastante visible en el árbol de la cruz. La decoración consiste en tiras de ochos, como ya se ha dicho, óvalos, flores, capullos de flores y haces de rayos labrados a bisel de diferente longitud entre

\footnotetext{
${ }^{50}$ COTS MORATÓ, Francisco de Paula, Los plateros valencianos en la edad moderna (Siglos XVI-XIX). Repertorio biográfico. Valencia: Universitat de València, 2005, pp. 129-131.

51 COTS MORATÓ, Francisco de Paula, 2005 (n 50), pp. 838-840.

52 Sacra de la Consagración: 57 x 50, Sacras del Evangelio y Lavabo: 40 × $31 \mathrm{~cm}$.

${ }^{53}$ Altura: 141, anchura: 80, longitud del asta: $176.5 \mathrm{~cm}$.
} 


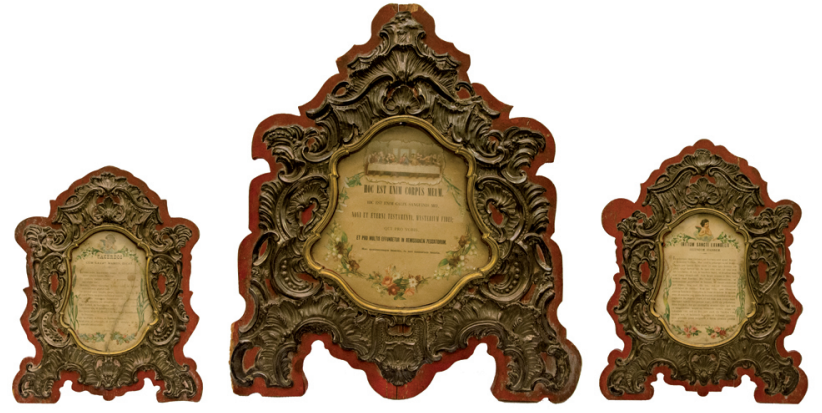

Fig. 12. Josep Bellmont. Juego de sacras. 1757-1761. Foto V. Iborra.

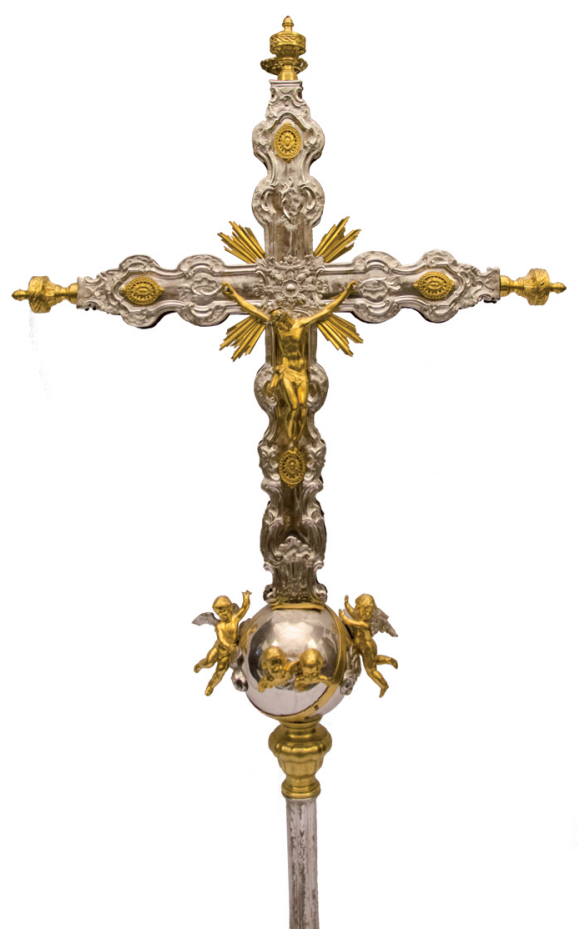

Fig. 13. Obrador de los Quinzà. Cruz procesional. ¿Década de 1780 ? Foto V. Iborra.

los brazos. Aunque la rocalla esté muy presente, los principales motivos ornamentales son clásicos.

Hace años la datamos ca. 1775, como la de Cocentaina (El Comtat), ${ }^{54}$ pues la mayoría de la decora- ción, como las tiras de ochos, ya están en la desaparecida Custodia de la Minerva de la Seo de Xàtiva (La Costera), de 1775. El globo cósmico de la cruz la relaciona especialmente con las "custodias escultóricas" del obrador de los Quinzà: la de Santa María la Mayor de Oliva (La Safor) (1770), la de la Minerva, ya mencionada, y la de la iglesia de la Asunción de Gorga (El Comtat) (ca. 1810). Los globos cósmicos son originarios de la platería de Nápoles y Sicilia, de donde los toma la orfebrería valenciana. Están presentes en las custodias, aunque conocemos otra cruz que lo tiene: la de la iglesia de Santa María de Cocentaina ${ }^{55}$ (El Comtat) (Fig. 14).

Esta última también está formada por planchas de plata blanca que se disponen sobre una base de madera, con adendas de cobre dorado. La ornamentan hojas de acanto, óvalos, rocallas y flores. El asta tiene magníficas rocallas y flores. Se diferencia de la de Algemesí en que es un poco más pequeña y posee el relieve de la Asunción en crucero del reverso, ya que este misterio de María es el titular de la parroquia de El Comtat. De la misma manera, los pomos muestran cenefas de hojas de acanto en vez de las tiras de ochos entrelazados. Ostenta las marcas de los Quinzà y la segunda de Antonio López (17341792?), autores y marcador de la pieza respectivamente. Son las mismas que figuran en el Relicario de la capa de san Vicente Ferrer de la Seo de Valencia, 1780, obra de Gaspar Quinzà (17001783), que es el platero de la Seo en esos años. Antonio López es maestro de oro, mayoral primero y marcador en dos ocasiones: 1779/1780 y $1785 / 86 .{ }^{56}$ Hoy en día el único problema es saber si la Cruz de Cocentaina es del padre, Gaspar, o del hijo, Bernat, ya que sus marcas son prácticamente iguales. Los dos rigieron el obrador familiar, aunque Bernat ya tenía un gran protagonismo antes, incluso, de estar examinado, según se desprende de algunas anotaciones del Libro de la Verdad del escultor valenciano José Esteve Bonet (1741-1802). ${ }^{57}$ Si la Cruz se hubiera marcado en 1779/80, correspondería la autoría a Gaspar, quien todavía es el titular del obrador y fallece en Valencia en 1783. De lo contrario, habría que adjudicársela a Bernat.

${ }^{54}$ COTS MORATÓ, Francisco de Paula, "Estructura y evolución formal en las cruces parroquiales valencianas (ss. XIV-XX)", Ars Longa, 21 (2012), pp. 130-131.

${ }^{55}$ Altura: 106, anchura: 78.5, longitud del asta: $170 \mathrm{~cm}$.

56 COTS MORATÓ, Francisco de Paula, 2005 (n 50), p. 505.

57 IGUAL ÚBEDA, Antonio, José Esteve Bonet. Imaginero valenciano del siglo XVIII. "El Libro de la Verdad". Valencia: Institución Alfonso el Magnánimo. Diputación Provincial de Valencia, 1971, pp. 31-32. 
La iglesia de Cocentaina también conserva una bella custodia procesional, de las "escultóricas", de plata blanca y dorada de 1805 . Fue labrada por otro miembro de esa familia: José Carlos Quinzà y Palop (1802-1847), asimismo platero de la Seo después de su padre y abuelo. Por lo que se ha dicho, concluimos que la Cruz de Algemesí es del mismo obrador ${ }^{58}$ que la de Cocentaina, aunque desconocemos, de momento, cuál de las dos fue labrada primero. El que no posea marcas es debido, seguramente, porque habría mucha confianza entre el artista y el comitente cuando acordaron la factura y entrega de la cruz.

La basílica de Algemesí conserva dos cálices de considerable mérito artístico. El primero es de plata blanca, batida y fundida. ${ }^{59}$ La copa es de plata dorada, la base es elevada y el nudo piriforme (Fig. 15). Presenta tres marcas bastante borradas en la pestaña de la base, donde apenas se aprecia la $L$ coronada de Valencia. Llaman la atención las cintas resaltadas que seccionan radialmente la base, de clara tradición deciochesca, y las tiras de cordoncito clásicas en la parte superior de la subcopa. Como indica una inscripción de la pestaña de la base, fue regalo del ermitaño de la Virgen de la Salud en 1800: "A ECX' DE MANUEL ASSENSY Y SOLER HERMITA ${ }^{\circ}$ DE ${ }^{R A}$ SEÑO ${ }^{A}$ DE LA SALUD AÑo 1800". Este cáliz está en la línea de esas obras que no terminan de abandonar el gusto rococó aunque incorporan algunos ornamentos -tiras de cordoncito- clásicos.

El otro cáliz ${ }^{60}$ es una bellísima pieza de ca. 1830. De plata dorada, batida, cincelada y repujada, descansa sobre una elevada peana circular y el nudo, que forma gran parte del astil, es troncocónico invertido, estructura muy utilizada en las piezas del siglo XIX (Fig. 16). Forman la decoración hojas de acanto, bonitas guirnaldas de hojas y flores, tiras de cordoncito y medallones con los Arma Christi en la sotocopa -lanza y caña con la esponja, tres clavos y corona de espinas, túnica de una pieza-, todo muy a gusto del clasicismo. Cabe añadir que, a partir del Rococó, hay un resurgir de lo icónico que no desaparecerá hasta la actualidad, aunque, como ya se ha indicado, muchas veces la cultura icónica decae, en algunos casos, entrado el siglo XX. No hemos visto marcas en él.

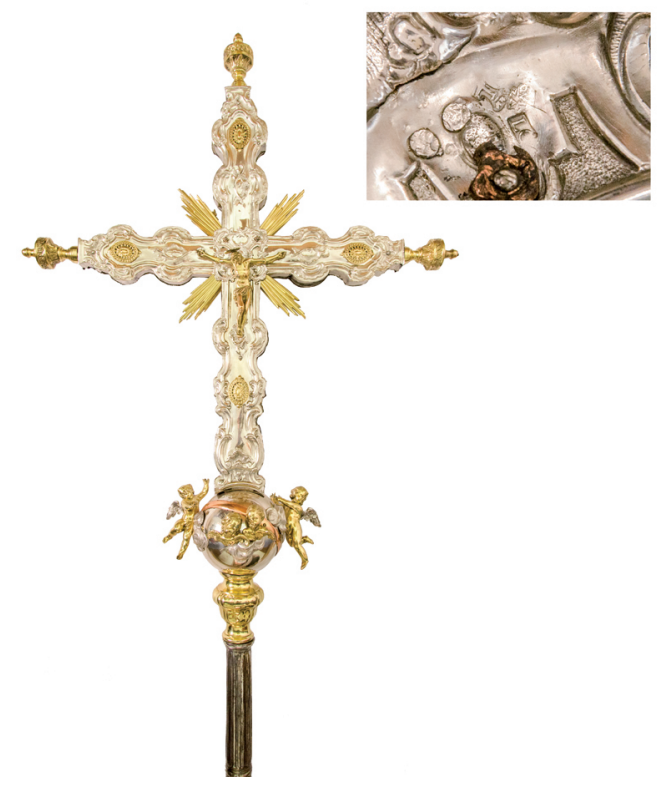

Fig. 14. Obrador de los Quinzà. Cruz procesional. Década de 1780. Iglesia parroquial de Santa María de Cocentaina. Foto V. Iborra.

Con ánimo de aumentar y reponer el ajuar de la iglesia así como todas aquellas piezas necesarias para el culto, la parroquia de San Jaime mandó labrar, después de la guerra civil, varias obras de platería y también algunos devotos colaboraron en su aderezo. Entre ellas, aparte de las ya estudiadas, está el respaldo de la imagen de la Virgen de la Salud, que se utiliza solamente en las procesiones. El orfebre José Bonacho David lo realizó en 1952. ${ }^{61}$ Este, junto con la diadema de 1943 y la corona de 1950 , completa lo necesario para las salidas anuales de la imagen. La donante fue la misma persona que costeó la diadema labrada por Francisco de Paula Pajarón Suay. Este respaldo, de plata dora$\mathrm{da}^{62}$ cincelada y repujada, tiene la forma alargada de una peineta valenciana y ostenta una Excelencia, la fuente (Cant 4, 12), y el Anagrama de María. Sus formas se inspiran en los motivos ornamentales del Barroco y Rococó valencianos, con las consabidas "ces", "eses", acantos, guirnaldas de flores y

\footnotetext{
${ }^{58}$ Esta cruz ha sido estudiada, aunque sus marcas no del todo bien identificadas por LÓPEZ CATALÁ, Enrique. "Cruz procesional". En: HERNÁNDEZ GUARDIOLA, Lorenzo, SÁEZ VIDAL, Joaquín y PARREÑO SANJUÁN, Javier (com.). La Luz de las Imágenes. Alacant (Catálogo de Exposición). Salamanca: Generalitat Valenciana, 2006, ficha $n^{\circ} 205$, pp. 568-569.

${ }^{59}$ Altura: 25.3 , base: 14.3 , copa: $8.5 \mathrm{~cm}$.

${ }^{60}$ Altura: 25.3 , base: 14.1 , copa. $8 \mathrm{~cm}$.

${ }^{61}$ FERRI CHULIO, Andrés de Sales, 2004 ( $n^{\circ}$ 5), p. 237.

${ }^{62}$ Altura: 72.5, anchura máxima: $34 \mathrm{~cm}$.
} 


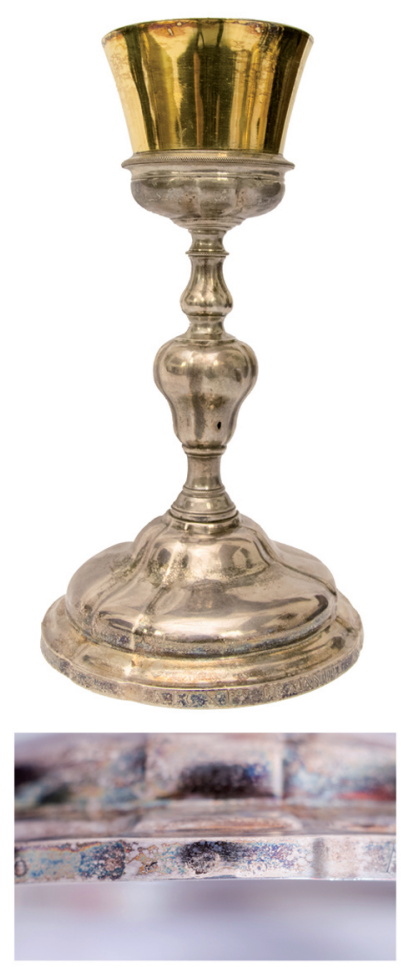

Fig. 15. Anónimo valenciano. Cáliz. 1800. Foto V. Iborra.

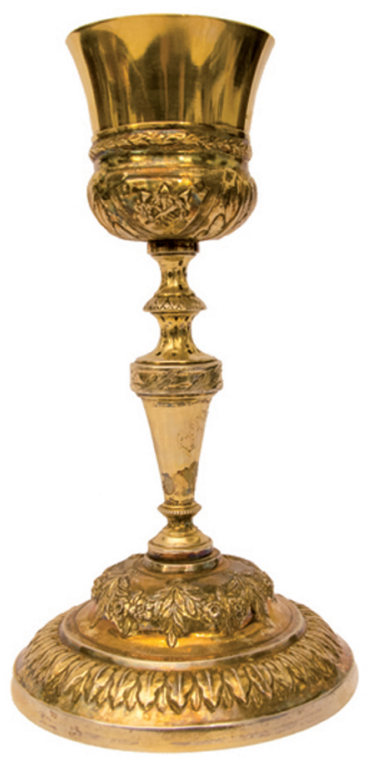

Fig. 16. Anónimo. Cáliz. Ca. 1830. Foto V. Iborra. haces de rayos de diferente longitud con cabezas de angelitos alados. Tiene una inscripción en la parte baja que reza así: "OBSEQUIO QUE LA SRTA. AMPARO NICLÓS ESTEVE OFRECE A NRA. SRA. DE LA SALUD PATRONA DE ALGEMESÍ DE SUS DOS HERMANOS D. JUAN Y D. RAMÓN PRESBíTEROS MARTIRIZADOS POR DIOS Y POR ESPAÑA EL 24 DE DESEBRE 1936. ALGEMESI 24 SEBRE 1952".

José Bonacho, hijo, fue el autor de la Urna-sepulcro de la beata Josefa Naval Girbés, ${ }^{63}$ realizada en 1988 según el diseño de Eduard Sarrió Gonzalvo. La donante fue la misma persona que costeó la lámpara del siglo XVIII, ya analizada, y que se conserva en la misma capilla. Es una gran caja acristalada por los cuatro lados, de bronce y cobre dorados con numerosos adornos de plata blanca. Está inspirada en los sepulcros y relicarios tradicionales que permiten una perfecta visión de la figura yacente por todos los lados, como si de una urna procesional se tratara. Es de gusto "clásico", con frontones y adornos arquitectónicos. Recorre la parte superior una balaustrada rematada por jarrones con azucenas, símbolos de la pureza de la beata Naval Girbés. De ella penden guirnaldas de flores de plata blanca y de tradición dieciochesca. En el centro de la parte superior tiene el escudo de la basílica de San Jaime en una cartela de plata blanca. En el centro de la inferior, una inscripción hace referencia a las reliquias y la cronología de la bienaventurada:

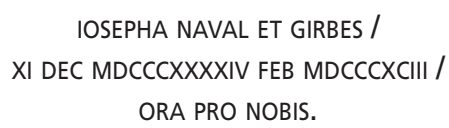

Como se ha visto, la basílica de San Jaime de Algemesí cuenta con un ajuar de platería destacado, con piezas datadas principalmente desde el siglo XVI hasta finales del siglo XX. Aunque la documentación sobre ellas no se conserva en el archivo parroquial, las características formales de las obras permiten asignarlas, sin apenas dudas, al obrador de Valencia. No se conserva el "hermoso viril" que refiere Ballester Broseta, pero sí están muchas otras piezas que vienen de antaño, sobre todo, el Relicario del Lignum Crucis, muy similar, aunque anterior, al de la parroquia de San Antonio Abad de Alginet (La Ribera Alta). El estudio de estas obras aumenta un poco más el conocimiento que tenemos de la platería valenciana de la edad moderna y contemporánea. La persistente labor de campo contribuirá en el futuro a rescatar del olvido numerosas obras de arte aún por catalogar.

${ }^{63}$ Altura: 95, anchura: 90, longitud: $198 \mathrm{~cm}$. 